\section{The Canada Research Chairs Program}

\section{Glen A. Jones}

Glen A. Jones is associate professor of higher education and chair of the Department of Theory and Policy Studies in Education, Ontario Institute for Studies in Education of the University of Toronto, 252 Bloor Street West, Toronto, Ontario, Canada, M5S IV6.

E-mail:<gjones@oise.utoronto.ca>.

$\mathrm{F}$ ollowing several years of discussion, lobbying, and speculation, the government of Canada, in its 2000 budget, announced the creation of a new university-focused research infrastructure, entitled the Canada Research Chairs Program (CRC). The program has significant implications for Canadian higher education, both because of the magnitude of the associated funding and because the CRC is one of several new programs that, taken together, signal a significant shift in the role of Canada's federal government in higher education.

Like many other governments, Canada's has grown more concerned as to whether the nation is positioned to compete effectively in the evolving, international "knowledge-based" economy. Concerns have been raised about whether Canadian universities can compete in the international academic labor market. The special challenge for Canada has been to strengthen a national research infrastructure that already relies quite heavily on universitybased research activity (with a lower level of private-sector investment in research and development compared to many of its OECD peers) in the context of a provincially regulated, relatively homogeneous, publicly supported university sector that is associated with one of the highest participation rates in the world. Through the CRC initiative, the government of Canada will reinforce the central role of universities within the country's research infrastructure with the creation of 2,000 research chairs by 2005 . The level of financial support associated with this new program is enormous. The 2000 budget announced an initial allocation of Can\$900 million; by 2004-2005, the program will have an annual budget of over Can\$2 billion.

\section{The Shifting Role of the Federal Government}

The CRC initiative signals an important shift in the federal government's role in Canadian higher education. For 30 years, Canada's approach to higher education policy has been extremely decentralized. Like most federal states, the responsibility for education was assigned to local provinces under the constitutional arrangement, but while federal governments in many other countries found mechanisms to assert a national influence over higher education policy, the notion of a stronger federal presence in the higher education policy was regarded as a threat to the delicate tenor of Canada's ongoing constitutional conversation. The federal government provided only indirect operating support to postsecondary education through unconditional transfers to the provinces. The provincial governments assumed the central role in regulating and providing direct operating support to universities and community colleges.

The federal government's direct involvement in higher education policy was limited to a number of policy areas viewed as more legitimate in the sensitive context of federal-provincial relations, including research. Until quite recently, the vast majority of federal government support for university research involved allocations to three national granting councils (the former Medical Research Council, now a component function of the new Canadian Institutes of Health Research; the Natural Sciences and Engineering Research Council; and the Social Sciences and Humanities Research Council). Each council operated research grant programs in which decisions on investigator-initiated research proposals were made through a process of peer review. A unique aspect of this funding arrangement was that, unlike parallel arrangements in many other jurisdictions, most of these grant mechanisms provided support for the direct costs of research activity but not for indirect costs (such as faculty time devoted to the project, university administrative costs, and other forms of overhead). Under the guise of furthering Canada's university research infrastructure, the CRC is clearly strengthening the federal government's direct involvement and influence in the higher education policy arena since the initiative focuses on central elements of the university operating budget: the faculty complement and related infrastructure costs.

\section{Concerns have been raised about whether Canadian universities can compete in the increasingly international academic labour market.}

\section{The Allocation Process}

Another important aspect of the CRC is that instead of creating a competitive process and calling for individual faculty or research network submissions, the new research chairs are allocated on the basis of prior support obtained by each institution in research grant competitions conducted by the three federal granting councils. In other words, significant levels of support are being awarded on the basis of prior relative success. Over 12 percent of all funding will be allocated to a single institution, the University of Toronto. While 57 universities are currently 
positioned to benefit from the initiative, 829 ( 41 percent) of the 2,000 research chairs will be allocated to only 5 universities (Alberta, British Columbia, McGill, Montreal, and Toronto) with 6 percent of chairs being specially allocated to smaller universities. Given that there has been a general assumption that Canadian universities are roughly equal in quality and homogeneous in institutional form, one possible impact of the CRC program may be the emergence of a more diverse university sector with an institutional hierarchy based on research intensity.

The CRC allocation protocols prescribe the share of research chairs that will fall under each of three broad research areas: 45 percent for natural sciences and engineering; 35 percent for health; and 20 percent for social sciences and humanities. The regulations also establish a framework for the distribution of chairs between a combination of existing faculty research "stars" and new appointments, though each university will have flexibility in determining how best to use CRC funds to strengthen its research infrastructure.

While program regulations prescribe the number of chairs that each institution will receive, universities have considerable autonomy in allocating the chairs within each institution, though the procedures and timelines of this decision-making process represent another important deviation from Canada's traditional approach to research funding. Prior to 2000, institutional research plans were essentially a synthesis of investigator-initiated research plans with the investigator or research team as the unit of analysis. The CRC approach assumes the existence of a rationally planned and managed university research enterprise. Given that the CRC program guide was disseminated in April 2000 and university research plans had to be submitted within five months, the processes employed to develop these statements of research priorities ranged from autocratic administrative decrees to ostensibly participatory planning exercises conducted during a time period when it was difficult for many active researchers to participate. In short, the planning process was largely at the discretion of university administrators and frequently bypassed traditional academic decision-making structures.

The CRC is one of a number of recent initiatives designed to increase the research capacity of Canadian universities, including the creation of the Canadian Foundation for Innovation, the Canadian Institutes of Health Research, and a number of new provincial government research funding mechanisms. Aside from providing additional resources for university research, these initiatives will undoubtedly have an important impact on the current institutional arrangements and they signal potentially dramatic shifts in what was a unique, Canadian approach to higher education policy.

\section{Endowing African Universities-Success Stories}

\section{Ellen Mashiko}

Ellen Mashiko is executive director, Scholarship Division of the Tokyo Foundation, Japan. Address: Hibiya Central Building $10^{\text {th }}$ Floor, 1-2-9 Nishishinbashi, Minato-ku, Tokyo 105-0003 Japan. Tel: +81-3-35029567; fax: +81-3-3502-9436; e-mail: <mashiko@tkfd.or.jp>; Internet: <http://www.tkfd.or.jp/eng/scholar/index.html>.

$\mathrm{F}$ ollowing Damtew Teferra's clear argument in this newsletter (see International Higher Education no. 20) in support of endowing universities on African soil, the cases of three universities may serve to demonstrate that endowments can be well managed, contribute to institutional sustainability, and lead to transnational collaboration with students, faculty and administrators throughout the world.

The three institutions are the University of Nairobi, the American University of Cairo, and the University of the Western Cape. Each institution received a U.S.\$1 million endowment under the Ryoichi Sasakawa Young Leaders Fellowship Fund (SYLFF) Program, a collaborative project of the Nippon Foundation and the Tokyo Foundation. The same conditions applied in each case-that is, the universities should be committed to managing the endowments to ensure that a predetermined portion of the earnings are returned to the capital to sustain growth over the long-term and use disposable income to provide fellowships to graduate students in the social sciences and humanities. Each institution is empowered to administer the fellowship program and to promote follow-up programs that are separately implemented and funded by the Tokyo Foundation.

Endowing African universities is not an audacious initiative but a sound investment in the future by the recipient and the donor.

\section{Profile of Endowments and Contributions}

When the University of Nairobi received its SYLFF endowment in 1989, it already had one other small endowment for general institutional support that was established in 1970 during its period as the University College Nairobi. The university has sought additional endowments from national and international sources but has not received further contributions thus far. 